\title{
Viral lysis modifies seasonal phytoplankton dynamics and carbon flow in the Southern Ocean
}

\author{
Tristan E. G. Biggs ${ }^{1,2}$, Jef Huisman ${ }^{2}$ and Corina P. D. Brussaard ${ }^{1,2}$ \\ (c) The Author(s) 2021
}

Phytoplankton form the base of marine food webs and are a primary means for carbon export in the Southern Ocean, a key area for global $\mathrm{pCO}_{2}$ drawdown. Viral lysis and grazing have very different effects on microbial community dynamics and carbon export, yet, very little is known about the relative magnitude and ecological impact of viral lysis on natural phytoplankton communities, especially in Antarctic waters. Here, we report on the temporal dynamics and relative importance of viral lysis rates, in comparison to grazing, for Antarctic nano- and pico-sized phytoplankton of varied taxonomy and size over a full productive season. Our results show that viral lysis was a major loss factor throughout the season, responsible for roughly half (58\%) of seasonal phytoplankton carbon losses. Viral lysis appeared critically important for explaining temporal dynamics and for obtaining a complete seasonal mass balance of Antarctic phytoplankton. Group-specific responses indicated a negative correlation between grazing and viral losses in Phaeocystis and picoeukaryotes, while for other phytoplankton groups losses were more evenly spread throughout the season. Cryptophyte mortality was dominated by viral lysis, whereas small diatoms were mostly grazed. Larger diatoms dominated algal carbon flow and a single 'lysis event' directed $>100 \%$ of daily carbon production away from higher trophic levels. This study highlights the need to consider viral lysis of key Antarctic phytoplankton for a better understanding of microbial community interactions and more accurate predictions of organic matter flux in this climate-sensitive region.

The ISME Journal (2021) 15:3615-3622; https://doi.org/10.1038/s41396-021-01033-6

\section{INTRODUCTION}

Phytoplankton blooms are the net result of gross growth minus losses [1] and the type of loss factor determines the flow of carbon and nutrients through the ecosystem [2]. Hence, studies that quantify viral lysis and grazing rates, and their functional significance throughout the productive season are greatly warranted. Zooplankton grazing is traditionally viewed as the dominant loss factor of phytoplankton cells [3], however, phytoplankton are also prone to viral infection [4-6]. Indeed, grazing rates do not always control primary production [7] and viral lysis may cause the collapse of phytoplankton populations $[8,9]$. In contrast to grazing, viral lysis predominantly channels particulate organic carbon and nutrients away from higher trophic levels $[2,10]$. The virus-induced release of host cellular content into surface waters fuels the so-called 'viral shunt' [11], whereby microbial processing of the released cell material directly affects biogeochemical cycling $[12,13]$. All phytoplankton taxonomic groups are prone to infection by viruses [14-16] and the typically high host specificity of the lytic algal viruses can have a further regulatory influence on phytoplankton species succession [9, 17-19]. Although temporal variations in the relative magnitude of viral lysis and grazing could directly affect phytoplankton community composition and trophic transfer efficiency, studies on the seasonal dynamics of viral lysis rates in phytoplankton communities are scarce. Moreover, most knowledge on phytoplankton-virus interactions is from temperate oceans and coastal waters, whereas very little is known about the extent to which viral losses may affect phytoplankton populations in the cold, productive waters of the Antarctic $[12,20,21]$.

The Southern Ocean is one of the largest carbon sinks of the global ocean $[22,23]$. Its low temperatures are responsible for a relatively high solubility of carbon dioxide $\left(\mathrm{CO}_{2}\right)$ and extensive phytoplankton blooms in the Southern Ocean absorb large amounts of $\mathrm{CO}_{2}$ for photosynthesis and growth [24, 25]. Primary production in Antarctic waters directs ecosystem productivity [26] sustaining large populations of copepods and krill [27] that in turn provide food for higher trophic levels (marine fish, birds and mammals) [26, 28, 29]. Portions of primary and secondary production become stored in the ocean interior by the biological carbon pump [30] and the formation of deep ocean water masses such as Antarctic Bottom Water and Antarctic Intermediate Water $[31,32]$. Ocean warming and acidification due to anthropogenic activities have been predicted to impact Antarctic phytoplankton species composition, i.e. by shifting from larger diatoms to smaller-sized flagellates [33-36], which will directly impact food quality and availability for higher trophic levels in the Antarctic pelagic food web. If this shift in community composition coincides with changes in grazing and viral lysis rates, subsequent changes in the flux of organic matter and energy can be expected,

\footnotetext{
${ }^{1}$ Department of Marine Microbiology and Biogeochemistry, NIOZ Royal Netherlands Institute for Sea Research, Texel, The Netherlands. ${ }^{2}$ Department of Freshwater and Marine Ecology, Institute for Biodiversity and Ecosystem Dynamics (IBED), University of Amsterdam, Amsterdam, The Netherlands. ${ }^{\circledR}$ email: tristan.biggs@nioz.nl; corina.brussaard@nioz.nl
} 
with implications for the biological carbon pump. A detailed seasonal study is therefore required for a better understanding of the ecological role of viral lysis for Antarctic phytoplankton dynamics.

Here we report the seasonal dynamics of viral lysis rates of Antarctic phytoplankton groups, including picoeukaryotes, the prymnesiophyte Phaeocystis spp., cryptophytes and nano-sized diatoms. Our results reveal that viruses not only exert a major control over the population dynamics of these key phytoplankton groups, but that viral lysis is also critically important for obtaining a complete seasonal mass balance. These findings call for a reconsideration of the microbial food web and the efficiency of the biological carbon pump in this climate-sensitive region.

\section{MATERIALS AND METHODS \\ Sampling site and procedure}

This study was conducted at the Rothera time series site (RaTS, latitude $67.572^{\circ} \mathrm{S}$; longitude $68.231^{\circ} \mathrm{W}$ [37]; located in Ryder Bay on the Western Antarctic Peninsula (Fig. S1). Samples were taken over a productive season from December 2012 to March 2013. Discrete seawater samples were collected from $15 \mathrm{~m}$ depth by a $12 \mathrm{~L}$ Niskin bottle deployed from a small boat. Full water column profiles were obtained using a SeaBird 19+ conductivity, temperature, depth instrument supplemented with a LiCor photosynthetically available radiation and an in-line fluorescence sensor (WetLabs). Sampling was conducted approximately once per week and processed directly upon return to the research base in a temperaturecontrolled lab $\left(\sim 0.5-1^{\circ} \mathrm{C}\right)$

\section{Phytoplankton}

Seawater samples (1-8L) were analysed for Chlorophyll $a$ (Chl-a) concentration and for other pigments to determine taxonomic composition using high performance liquid chromatography (HPLC; see ref. [36] for details).

For phytoplankton enumeration (of single cells), $3.5 \mathrm{~mL}$ sub-samples were fixed with $100 \mu \mathrm{L}$ formaldehyde-hexamine $(18 \% \mathrm{v} / \mathrm{v}: 10 \% \mathrm{w} / \mathrm{v})$ at $4{ }^{\circ} \mathrm{C}$ for 15-30 min, after which they were snap-frozen in liquid nitrogen and stored at $-80^{\circ} \mathrm{C}$ until analysis. Samples were analysed according to [38] using a Becton Dickinson FACSCalibur flow cytometer equipped with an air-cooled Argon laser with an excitation wavelength of $488 \mathrm{~nm}(15 \mathrm{~mW})$ and the trigger was set on red fluorescence. Phytoplankton populations $(\leq 20 \mu \mathrm{m})$ were distinguished using bivariate scatter plots of red Chl- $a$ autofluorescence versus side scatter. Cryptophytes were discriminated based on their orange phycoerythrin auto-fluorescence [39]. The flow cytometry data files were analysed using the freeware CYTOWIN [40]. No indications of chains or colonies were found in the cytograms and no significant difference was found in phytoplankton population counts between live and fixed samples (Mann-Whitney Rank Sum Test: $n=44$ and $p=0.24$ ).

Over the course of the season (and also using flow cytometry data from a consecutive season) ten phytoplankton populations could be distinguished, Phyto I-X, with average cell diameters of $0.9,1.8,3.1,4.0,4.5,4.5$, 7.4, 8.1, 11.5 and $20.4 \mu \mathrm{m}$ (Fig. S2) [36]. The Phyto III population was identified as Phaeocystis spp. based on microscopic identification and resembling temporal dynamics with Prymnesiophyceae $\mathrm{Chl}-a$ as measured by HPLC [36]. Phyto IV were identified as cryptophytes based on flow cytometry counts and phycoerythrin orange auto-fluorescence, microscopic identification and matching temporal dynamics with Cryptophyceae $\mathrm{Chl}-a<20 \mu \mathrm{m}$ measured by HPLC. Phyto V-X were identified as diatoms based on microscopic confirmation of different diatom size classes and, at times they dominated, showed good comparisons between flow cytometry carbon and the cellular carbon of the related diatom Chl- $a$ size fractions $(<5,5-20$ and $>20 \mu \mathrm{m}$, measured by HPLC after size fractionation) [36]. The standing stock of Phyto VII and X were consistently low $\left(<50 \mathrm{~mL}^{-1}\right)$ and were not included for rate analysis.

\section{Zooplankton, bacteria and viruses}

Larger-sized zooplankton $(>200 \mu \mathrm{m})$ were collected from surface waters $(200-0 \mathrm{~m})$ using a $200 \mu \mathrm{m}$ mesh ring net $\left(0.26 \mathrm{~m}^{2}\right.$ opening $)$ deployed from a small boat. Zooplankton samples were transported back to the laboratory in a portable cooler, preserved in $200 \mathrm{~mL}$ formaldehyde $(5 \%$ final concentration) and stored at $4{ }^{\circ} \mathrm{C}$ until abundances were determined using a binocular microscope. For more detailed methodology see Biggs et al. [41].
Samples for bacteria and viruses were fixed $0.5 \%$ final concentration EM-grade glutaraldehyde; Sigma-Aldrich, Zwijndrecht, The Netherlands), stored at $-80^{\circ} \mathrm{C}$ after being flash-frozen in liquid nitrogen, and counted after thawing using flow cytometry according to the protocol by Marie et al. [42] and by Mojica et al. [43], respectively. In short, thawed samples were diluted in TE buffer (10 mM Tris $\mathrm{HCl}, 1 \mathrm{mM}$ EDTA; $\mathrm{pH}$ 8.2) and stained with the nucleic acid-specific green fluorescent stain SYBR Green-I (Life Technologies, Bleiswijk, The Netherlands) to a final concentration of 1 and $0.5 \times 10^{-4}$ of the commercial stock at room temperature $(15 \mathrm{~min})$ and $80^{\circ} \mathrm{C}$ (10 min, after which the samples were cooled at room temperature in the dark for $5 \mathrm{~min}$ ) for bacteria and viruses, respectively. For flow cytometric counts, the trigger was set on green fluorescence with the bacteria and different virus populations distinguished based on their green fluorescence and side scatter signal (Fig. S3).

Five distinct virus populations (V1-V5) were identified based on their green fluorescence and side scatter signal (Fig. S3). The commonly observed marine virus populations $\mathrm{V} 1$ and $\mathrm{V} 2$ are considered to be dominated by bacteriophages, although eukaryotic algal viruses (e.g. small genome-sized Heterosigma or diatom viruses) can also display similar low fluorescence signatures [14, 44-46]. The V3-V5 clusters generally contain more algal viruses, with prokaryotic and eukaryotic algal viruses contributing to the V3 group, and the V4 and V5 groups generally containing larger double-stranded DNA algal viruses [4, 47-49].

\section{Growth and mortality rates}

To determine viral lysis and grazing rates of the identified phytoplankton populations, the predation pressures by smaller zooplankton $(<200 \mu \mathrm{m}$; such as tintinnids, ciliates, heterotrophic dinoflagellates and nanoflagellates) and viruses were experimentally manipulated using the modified dilution assay [6]. In short, natural seawater was gently passed through a $200 \mu \mathrm{m}$ mesh to remove larger-sized zooplankton such as large copepods and krill, and was then combined (by siphoning into $1 \mathrm{~L}$ clear polycarbonate bottles) with either $0.45 \mu \mathrm{m}$ (grazer-free) or $30 \mathrm{kDa}$ (grazer and virus-free) filtered seawater at four dilutions (100, 70, 40 and $20 \%$ whole water), in triplicate. The $0.45 \mu \mathrm{m}$ filtrate was prepared by gravity filtration of natural seawater through a $0.45 \mu \mathrm{m}$ Sartopore capsule filter with a $0.8 \mu \mathrm{m}$ pre-filter (Sartopore 2300, Sartorius Stedim Biotech, Göttingen, Germany). The $30 \mathrm{kDa}$ ultra-filtrate was prepared by tangential flow filtration using a polyethersulfone membrane (Vivaflow 200, Sartorius Stedim Biotech, Göttingen, Germany). The dilutions were transferred in the dark to an outdoor flow-through incubator and incubated on a slow turning wheel ( $\sim 0.5 \mathrm{rpm})$ at in situ temperature and light conditions (using neutral-density screens) for $24 \mathrm{~h}$. Phytoplankton were enumerated at the start and end of the incubation using flow cytometry (see above) and the apparent growth rate was calculated based on the natural logarithm. By using flow cytometry, the loss rates could be specified for each phytoplankton group. The (negative) slopes of linear regressions of the apparent growth rate versus the actual dilution factor provides both specific grazing ( $0.45 \mu \mathrm{m}$ series) and grazing + viral lysis ( $30 \mathrm{kDa}$ series) rates with viral lysis rates derived by subtraction [50]. In those cases where the slope of the linear regression was positive and $>0.1$, we considered that proper estimation of the grazing and viral lysis rates failed and the values were discarded [50]. In the case of missing replicates (e.g. due to technical error during the assay or flow cytometric analysis) or clear outliers (compared to the series, often when population abundance was low), we performed the regression analysis without those values. Actual dilution factors were determined by dividing the total phytoplankton count of the specific dilution (of the $0.45 \mu \mathrm{m}$ or $30 \mathrm{kDa}$ series) by the average total count of the $100 \%$ natural water. The $y$-axis intercept of the linear regression represents the gross specific growth rate ( $\mu_{\text {gross }}$ ), assuming the sum of the specific grazing and viral lysis rates of these phytoplankton $(\leq 20 \mu \mathrm{m})$ to equal the total specific mortality rate $\left(m_{t o t}\right)$.

\section{Carbon production and losses}

To calculate daily amounts of carbon produced by phytoplankton production and lost by grazing and viral lysis, we assume that the population dynamics of the phytoplankton can be described by a simple model:

$\frac{d X}{d t}=\left(\mu_{\text {gross }}-m_{\text {tot }}\right) X$

where $X$ is the phytoplankton concentration at time $t, \mu_{\text {gross }}$ is the gross specific growth rate, and $m_{\text {tot }}$ is the total specific mortality rate driven by viral lysis and grazing (i.e. $m_{\text {tot }}=m_{V}+m_{G}$ ). 
Assuming that the specific growth and mortality rates do not change over sufficiently short time intervals, this differential equation can be solved as:

$X(t)=X_{0} e^{\left(\mu_{\text {gross }}-m_{\text {tot }}\right) t}$

The total number of phytoplankton cells produced over a time interval of $T$ days $\left(P_{T}\right)$ can be calculated by integrating the production rate over time:

$P_{T}=\int_{0}^{T} \mu_{\text {gross }} X(t) d t$

Inserting Eq. (2) into Eq. (3) and subsequent integration gives:

$P_{T}=\frac{\mu_{\text {gross }}}{\mu_{\text {gross }}-m_{\text {tot }}}\left(X_{0} e^{\left(\mu_{\text {gross }}-m_{\text {tot }}\right) T}-X_{0}\right)$

Similarly, the total number of phytoplankton cells lost over $T$ days $\left(L_{T}\right)$ can be calculated as:

$L_{T}=\frac{m_{\text {tot }}}{\mu_{\text {gross }}-m_{\text {tot }}}\left(X_{0} e^{\left(\mu_{\text {gross }}-m_{\text {tot }}\right) T}-X_{0}\right)$

This total loss is partly due to viruses and partly to grazers. Specifically, the total number of phytoplankton cells lost over $T$ days by viral lysis is $\left(m_{V} / m_{\text {tot }}\right) L_{T}$ and by grazing is $\left(m_{G} / m_{t o t}\right) L_{T}$. We calculated daily rates, with a time interval of $T=1$ day, in-line with the $24 \mathrm{~h}$ incubation period used in the dilution assays.

To convert cell numbers to carbon, the total number of cells produced and lost (i.e. $P_{T}$ and $L_{T}$ ) were multiplied with the cellular $C$ content $(\mu \mathrm{gC}$ $\mathrm{cell}^{-1}$ ) of each phytoplankton group. The cellular $C$ content of each phytoplankton population was estimated from the average cell diameter,

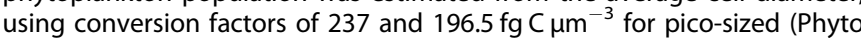
I-III) and nano-sized (Phyto IV-IX) phytoplankton populations, respectively $[51,52]$. To calculate total seasonal production and loss rates, we integrated daily carbon produced $\left(\mu_{\text {gross }}\right)$, grazed, lysed and lost $\left(m_{\text {tot }}\right)$ over the entire length of our sampling period (from 6 December 2012 to 12 March 2013) with linear interpolation between data points using $R$ statistical software (R Development Core Team 2012).

\section{Statistics}

According to the modified dilution assay $[4,6]$, a significant difference from zero for the grazing regression coefficient $(0.45 \mu \mathrm{m}$ series) indicates significant grazing rates, whilst a significant difference between the regression coefficients of the $0.45 \mu \mathrm{m}$ and $30 \mathrm{kDa}$ series (as tested by analysis of covariance, $p<0.05$, using R statistical software; R Development Core Team 2012) indicates significant viral lysis rates. A significant difference from zero for the regression coefficients of the $30 \mathrm{kDa}$ series indicates significant gross growth. Throughout the text the plus-minus symbol $( \pm)$ represents 1 standard deviation. Significant differences between viral lysis and grazing rates were tested using a two-tailed Student's $t$ test and a Mann-Whitney $U$ test if data deviated from normality as assessed by the Shapiro-Wilk test (SigmaPlot v14, from Systat Software, Inc., San Jose California, USA). The strength of the relationship between viral lysis and grazing rates was determined using Pearson's correlation (SigmaPlot v14).

\section{RESULTS AND DISCUSSION}

\section{Specific phytoplankton viral lysis rates}

This study details the specific viral lysis rates for eight different Antarctic phytoplankton populations throughout the entire Austral productive season. To our knowledge, this is the first detailed viral lysis rate study of multiple phytoplankton species during major seasonal changes in plankton community composition and size distribution, not only for coastal waters of the Western Antarctic Peninsula (Fig. S1), but for the entire Southern Ocean.

Although light microscopy of Lugol's fixed seawater samples revealed relatively high numbers of micro-sized centric diatoms in mid-December (measuring 25-60 $\mu \mathrm{m}$; unpublished data), the picoand nano-sized phytoplankton $\leq 20 \mu \mathrm{m}$ contributed $70 \%( \pm 22 \%$, $n=13$ ) to total Chl- $a$ over the entire season and their contribution increased to $77 \%( \pm 16 \%, n=11)$ from late December until the end of the season (Fig. S4). The temporal dynamics of the different phytoplankton groups (Fig. 1) and total Chl- $a$ concentration (Fig. S4) showed that at the start of the productive season (beginning of December) the smaller-sized Phyto I (average cell diameter of $0.9 \mu \mathrm{m})$, Phyto II $(1.8 \mu \mathrm{m} \varnothing)$, and Phaeocystis antarctica Phyto III $(3.1 \mu \mathrm{m} \varnothing)$ were numerically dominant $(58 \%, 16 \%$ and $10 \%$, respectively). Thereafter, the abundance of the diatom groups (Phyto $\mathrm{V}, \mathrm{VI}, \mathrm{VIII}$ and IX, 4.5-11.5 $\mu \mathrm{m} \varnothing$ ) increased during the 'spring' bloom in the second half of December. The 'spring' bloom was followed by dominance of smaller phytoplankton, particularly cryptophytes Phyto IV $(4 \mu \mathrm{m} \varnothing)$, driven by the relatively warm austral summer months [36]. Later in the productive season (February) when temperature was still relatively high, salinity had become relatively low due to melting ice and light was not yet limiting, Phaeocystis Phyto III and diatoms Phyto VI bloomed (Fig. 1). Finally, they were succeeded by diatoms Phyto IX during late summer and austral fall (mid-February to March) when light availability and nutrient (phosphate and nitrate) concentrations declined as a result of shorter daylengths, increased light attenuation and biological nutrient uptake [36]. Although we did not specifically identify the species of diatoms during the season, van Leeuwe et al. [53] observed relatively high numbers of Thalassiosira sp. (5-20 $\mu \mathrm{m}$ cell length) and Chaetoceros sp. (10-15 $\mu \mathrm{m}$ cell length) at the same location in January and February.

Overall, specific viral lysis rates were substantial for all phytoplankton groups (Fig. 1 and Table S1), with average lysis rates ranging between $0.23 \pm 0.38(n=13$, Phyto $\mathrm{Vl})$ and $0.42 \pm$ $0.39 \mathrm{~d}^{-1}(n=9$, Phyto IV). Comparatively high rates of viral lysis have previously been reported for picoeukaryotic phytoplankton $\left(0.23-0.81 \mathrm{~d}^{-1}\right)[54,55]$, for Phaeocystis globosa $\left(0.35 \mathrm{~d}^{-1}\right)$ [4] and for nano-eukaryotes (up to $0.89 \mathrm{~d}^{-1}$ ) [6]. The virus populations V4 and V5 (Fig. S3) resembled the flow cytometric signatures of large genome dsDNA algal viruses such as Phaeocystis viruses [4, 49], whereby the temporal dynamics of V4 matched best with Phyto III (Fig. S5a). The occurrence of potential eukaryotic algal virus populations together with considerable viral lysis rates seems to give support to our findings, however, flow cytometric analysis alone cannot provide certainty. Virus population V5 corresponded best with diatom Phyto VI (Fig. S5b), despite that thus far no large genome dsDNA viruses infecting diatoms have been reported.

Although diatom populations are known to be infected by viruses $[15,56,57]$, specific viral lysis rates for natural diatom populations have not yet been reported in the literature. Our results demonstrate that viral lysis of diatoms (i.e. Phyto V, VI, VIII and IX) can be substantial (Fig. 1E-H). They displayed a seasonally average viral lysis rate of $0.29 \pm 0.32 \mathrm{~d}^{-1}$, which is almost of equal magnitude as their seasonally averaged grazing rate of $0.35 \pm 0.27 \mathrm{~d}^{-1}$ (both $n=47$; Table S1). Antarctic diatoms often dominate high-biomass phytoplankton blooms and are an important source of primary nutrition as they are major producers of long-chain polyunsaturated fatty acids (such as 20:5 $\omega$-3) [58]. The consumption of diatoms has been reported to increase the sedimentation speed of fecal pellets due to the ballasting effect of biogenic silica [59, 60]. Instead, viral lysis will promote the recycling of dying host cells in surface waters [61]. Recent research, however, has shown that viral lysis may have the potential to also induce aggregate formation and potentially sedimentation [62].

\section{Ecological and seasonal importance of viral lysis}

Viral lysis rates varied over the season (Fig. 1A), with Phyto I displaying significantly higher grazing than lysis rates during the first half of the season (average $0.44 \pm 0.36 \mathrm{~d}^{-1}$ and $0.15 \pm 0.20 \mathrm{~d}^{-1}$, respectively; Mann-Whitney $U$ test: $U=16, n_{1}=n_{2}=9, p=0.034$ ). Nutrient depletion, as found at the end of December [36], could have negatively impacted virus production [63, 64], however, nutrient stress was brief due to mixing at the beginning of January. During the second half of the season (February and March), viral 

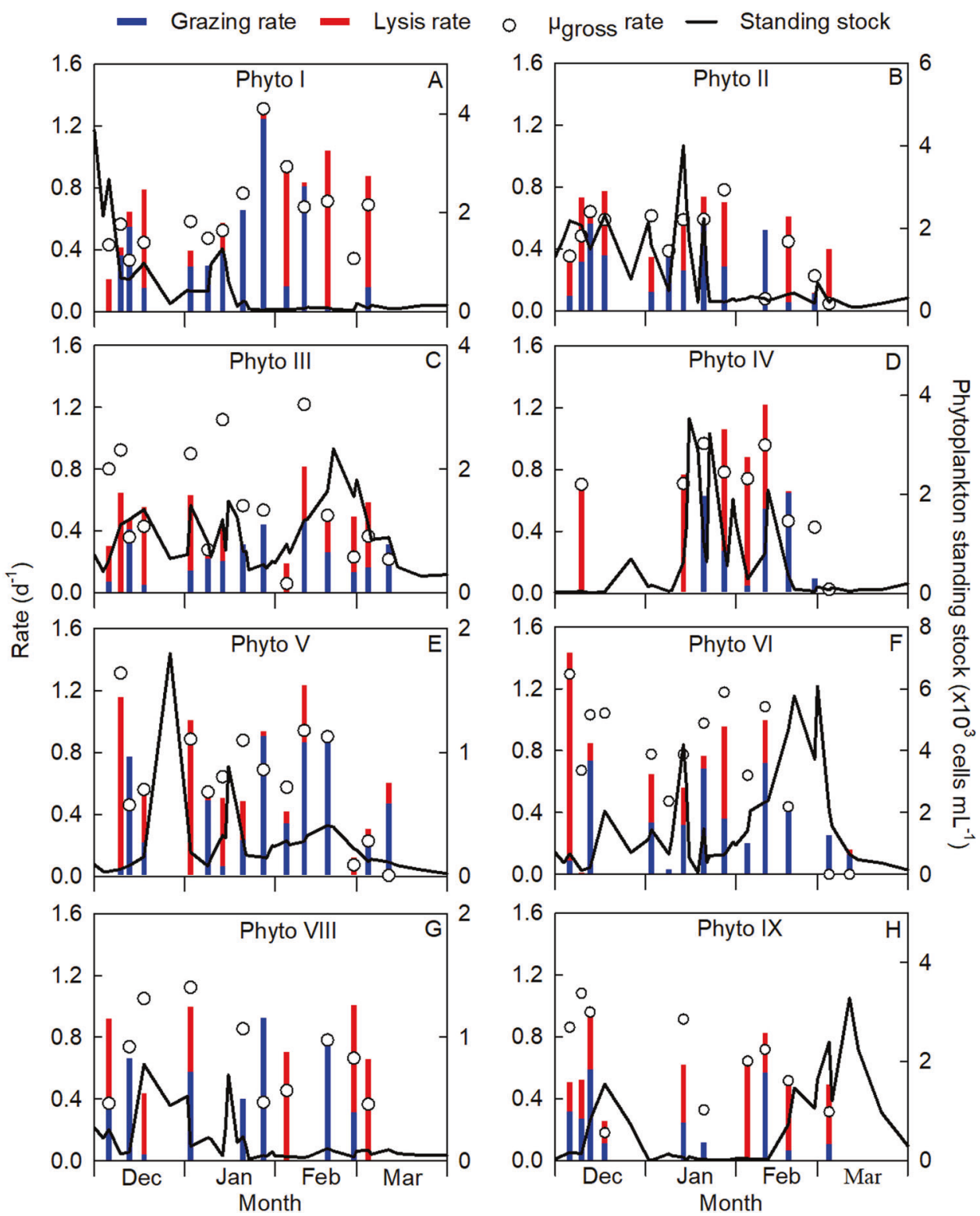

Fig. 1 Seasonal dynamics of phytoplankton standing stock (green line), specific gross growth rate ( $\mu_{\text {grossi }}$ open circles), viral lysis rate (red bars) and grazing rate (blue bars) for different phytoplankton groups distinguished by flow cytometry. The phytoplankton groups include (A, B) picoeukaryotes (Phyto I and II), (C) Phaeocystis (Phyto III), (D) cryptophytes (Phyto IV), and (E-H) diatoms of different size classes (Phyto V, VI, VIII and IX). Note that the scale for standing stock (right $y$-axis) differs between the panels; standing stock data are composed of $n=41$ data points.

lysis appeared to be the dominant loss factor for Phyto I $(0.52 \pm$ $0.47 \mathrm{~d}^{-1}$ compared to grazing $\left.0.23 \pm 0.33 \mathrm{~d}^{-1}, n=5\right)$, which may have contributed to its reduced standing stock (Fig. 1A). During the course of the blooms of Phaeocystis Phyto III and cryptophytes Phyto IV, their viral lysis rates were substantial $\left(0.30 \pm 0.26 \mathrm{~d}^{-1}\right.$ and $0.61 \pm 0.35 \mathrm{~d}^{-1}$, respectively; Fig. $\left.1 C, D\right)$. In contrast to Phyto I, Phyto $\mathrm{V}$ experienced high losses by viral lysis during the first half of the season $\left(0.45 \pm 0.44 \mathrm{~d}^{-1}, n=7\right)$ whereas during the second half the share of grazing was significantly higher $\left(0.53 \pm 0.37 \mathrm{~d}^{-1}\right.$ vs. lysis $0.12 \pm 0.12 \mathrm{~d}^{-1}$; Student's $t$ test: $t_{12}=2.787, n_{1}=n_{2}=7, p=$ 0.0164; Fig. 1E). Unlike Phyto III and IV, viral lysis rates were low for diatom Phyto VI $\left(0.06 \pm 0.12 \mathrm{~d}^{-1}\right.$; Fig. 1F) when they reached high abundances in February and March. Similar to Phyto I in the second half of the season, high lysis rates were measured for diatoms Phyto VIII and IX $\left(0.51 \pm 0.34 \mathrm{~d}^{-1}\right.$ and $0.42 \pm 0.14 \mathrm{~d}^{-1}$, respectively; Fig. $1 \mathrm{G}, \mathrm{H}$ ). Temporally separated populations of phytoplankton may exhibit variability in the susceptibility to both viral lysis and grazing depending on the life history of both predator (viruses and grazers) and prey (phytoplankton).

Our results show that high viral lysis rates coincide with low grazing rates and vice versa (Pearson's $r=-0.43, n=98, p<$ 0.0001; Fig. 2A), in particular for picoeukaryote Phyto I, Phaeocystis Phyto III and diatom Phyto V (Fig. 2B, Table S2). A negative correlation between viral lysis and grazing could arise from physiological control by the algal host cell, where an increase in the length of the latent period could be favourable for losses by grazing (i.e. cells have a greater chance of being grazed before cell lysis), in contrast to shorter latent periods that might favour losses due to viral lysis [64-68]. A negative correlation may also arise from direct or indirect interactions among grazers and viruses, such as preferential grazing on or avoidance of virally infected phytoplankton cells $[69,70]$, or direct grazing of (algal) viruses, for example by heterotrophic nanoflagellates [71]. The impact of larger-sized $(\geq 200 \mu \mathrm{m})$ zooplankton (Fig. S6) on smaller 


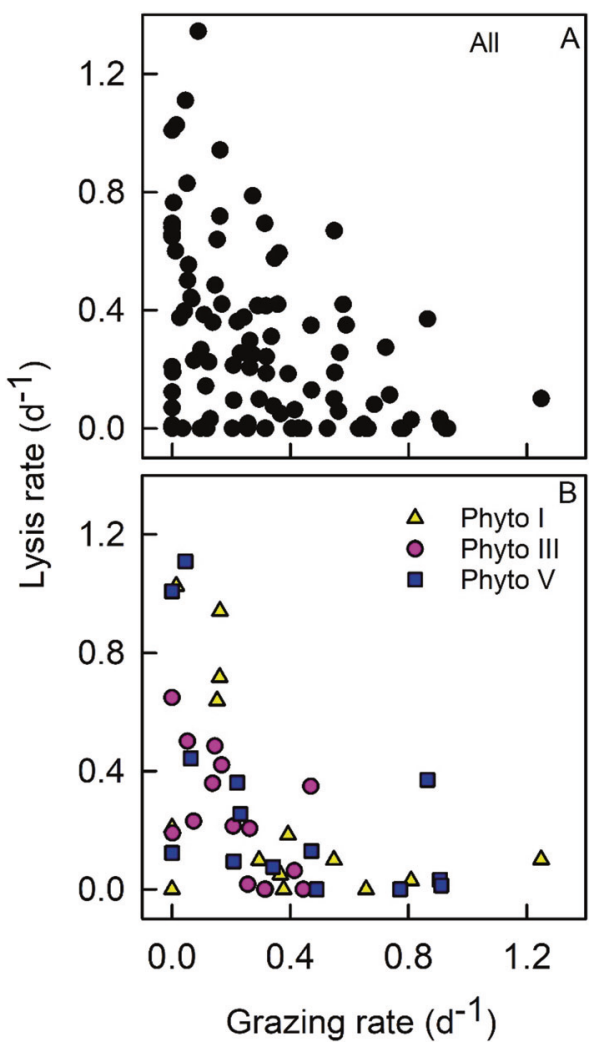

Fig. 2 Correlation of viral lysis and grazing rates. Specific viral lysis rates are plotted against grazing rates for $(\mathbf{A})$ all phytoplankton groups and (B) phytoplankton groups Phyto I, III and V only.

zooplankton $(<200 \mu \mathrm{m})$ could also influence the balance between the phytoplankton loss factors.

Net growth rates based on counts from the mortality assay (for distinct periods of abundance increase and decline, where experimental $n \geq 3$ ) aligned well with net growth rates obtained from in situ abundance dynamics (Fig. 3), indicating that the experimental rates (Table S1) provided a very good representation of actual growth and loss processes. Averaged over the entire productive season, specific viral lysis rates were comparable to grazing rates $\left(0.29 \pm 0.30 \mathrm{~d}^{-1}\right.$ and $0.31 \pm 0.27 \mathrm{~d}^{-1}$, respectively, $n=98$; Fig. $4 \mathrm{~A})$. The trend that viral lysis rates were of similar magnitude as grazing rates held for all major phytoplankton populations and taxonomic groups, i.e. picoeukaryotes, Phaeocystis, cryptophytes and diatoms (Fig. 4B). Furthermore, total mortality (sum of viral lysis and grazing) matched gross growth when averaged over the entire season (Fig. S7).

The ecological importance of viral lysis is highlighted by a closeto-zero mass balance of seasonal phytoplankton carbon production and losses when viruses are included as a loss factor (Fig. 5). Furthermore, differences in the slopes of the individual linear regressions (Fig. S8) suggest there were differences in the relation between carbon production and carbon losses among phytoplankton groups. The extent to which grazers and viruses can control different phytoplankton populations depends on multiple factors such as size class and abundance of phytoplankton, grazers and viruses, nutrient and light availability, susceptibility to grazing and viral lysis at each moment in time, and the ability of grazer and virus populations to keep up with increasing phytoplankton production [72]. Our data demonstrate that viral lysis is not only an important cause of mortality for Antarctic phytoplankton (of equal magnitude as grazing by smaller zooplankton) but also an essential process to be included for a better understanding of phytoplankton population dynamics.

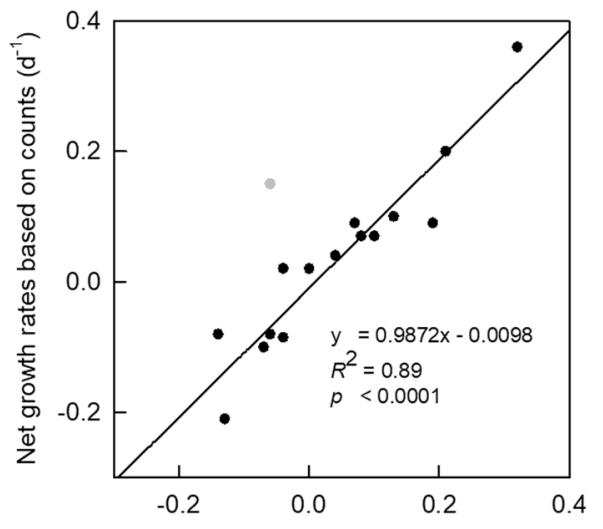

Net growth rates based on dilution experiments $\left(d^{-1}\right)$

Fig. 3 A comparison of net specific growth rates $\left(\mu_{\mathrm{NET}}\right)$ based on phytoplankton counts and on dilution experiments. Dilution experiment $\mu_{\mathrm{NET}}$ rates were averaged $(n \geq 3)$ over time periods of sustained increase and decrease in population abundance and compared to $\mu_{\text {NET }}$ rates estimated from in situ abundance counts over the same time period. Note: outlier shown in grey is not included in the linear regression.

Relatively high growth rates and comparably high total loss rates (grazing plus lysis) of the dominant Antarctic phytoplankton $(\leq 20 \mu \mathrm{m}$ fraction, typically ruling total Chlorophyll $a$; Fig. S4) suggests that loss processes are coupled to growth and indicate a rapid turnover of photosynthetically fixed carbon that helps to explain the relatively low concentration and slow build-up of biomass in comparison to available resources.

\section{Carbon flux and potential future implications}

Overall, viral lysis was a major loss factor responsible for a seasonal carbon flux of $2674 \mathrm{\mu g} \mathrm{CL}^{-1}$, which represented $58 \%$ of the total seasonal phytoplankton carbon losses $\left(4645 \mu \mathrm{g} \mathrm{CL}^{-1}\right)$ and $55 \%$ of the total seasonal phytoplankton carbon produced $\left(4821 \mu \mathrm{g} \mathrm{CL}^{-1}\right)$. The nano-sized diatoms accounted for the majority of the total cellular carbon grazed, lysed and produced $(91 \%, 91 \%$ and $91 \%$, respectively), whereby Phyto IX (average cell diameter $11.5 \mu \mathrm{m}$ ) contributed most $(55 \%, 71 \%$ and $56 \%$, respectively; data not shown). In contrast to smaller nano-sized diatoms such as Phyto VVIII, larger nano-sized diatoms such as Phyto IX are considered a suitable prey size for larger zooplankton such as copepods [73-75]. We did not estimate grazing rates by zooplankton $>200 \mu \mathrm{m}$, and hence we do not know the full extent to which Phyto IX was grazed. However, during the December spring bloom, the net growth rates of Phyto IX based on natural abundances $\left(0.20 \mathrm{~d}^{-1}\right)$ matched the average net growth rates of Phyto IX from the dilution experiments (mean $=0.21 \mathrm{~d}^{-1}, n=4$ ), suggesting the majority of losses were accounted for by the experimental incubations. Accordingly, losses by viral lysis of Phyto IX during the December experiments (spring bloom period) were most likely considerable (Table S3) as they diverted an estimated $30 \%$ of total diatom carbon produced $\left(91 \mu \mathrm{g} \mathrm{CL}^{-1}\right)$ away from higher trophic levels. Additionally, during the late summer bloom (dominated by Phyto IX, Fig. 1H) viral lysis can at least occasionally direct the vast majority of daily carbon produced towards the dissolved pool. For example, during the large 'lysis event' on 5 March, 124\% (135.5 $\mathrm{g} \mathrm{CL}^{-1} \mathrm{~d}^{-1}$ ) of daily carbon produced (109.4 $\mu \mathrm{g} \mathrm{CL}^{-1} \mathrm{~d}^{-1}$ ) was lost by viral lysis (Table S3). Such a considerable flux of organic matter from the particulate to dissolved fraction (viral shunt) stimulates bacterial production $[10,76]$ and hence may explain the strong increase in bacterial abundance at the end of the season (0.1-2.4 $\times 10^{6}$ cells $\mathrm{mL}^{-1}$ from mid-February to mid-March, Fig. S9). Virus mortality pressure may have been responsible for the subsequent decline in bacteria, as suggested by the peaks in total 
virus abundance in the second half of March and early April (Fig. S9). The substantial viral lysis of Phyto IX could have reduced phytoplankton food availability for key feeding stages of herbivorous copepods and may have impacted lipid accumulation (and annual reproductive success) at a crucial time prior to overwintering [41].

Climate change scenarios predict enhanced sea-ice loss in Antarctic waters [77] that is likely to increase the length of the productive period [78, 79]. However, earlier and strengthened stratification (due to higher temperatures and ice melt) [80-82] will reduce the flux of dissolved inorganic nutrients to surface waters [83] and is predicted to promote a more flagellatedominated community (cryptophytes Phyto IV, Phaeocystis Phyto III) with less larger-sized diatoms during the summer months $[36,84-86]$. Our study shows that viral lysis was a major loss factor for cryptophytes and Phaeocystis (Fig. 4B). The share of viral lysis as compared to grazing is therefore expected to increase, even if these flagellates become more dominant. Moreover, ocean acidification has been shown to diminish diatom silicification
[33] and if this results in silicate stress for the (smaller-sized) diatom cells, viral infection and mortality of diatoms could be enhanced [56]. Under these future scenarios, our study implies that viral lysis will play a more prominent role, reducing trophic level transfer efficiency and ecosystem productivity.

Our study demonstrates that viral lysis not only implements decisive control over the seasonal dynamics of the different ecologically important Antarctic phytoplankton groups (picoeukaryotes, the prymnesiophyte Phaeocystis spp., cryptophytes and diatoms), but also reveals how imperative it is to include viral lysis in mass-balance calculations. Mathematical models that involve Antarctic phytoplankton dynamics and seasonal mass balance, but do not account for viral lysis derived losses, are likely to overestimate the impact of grazing. Our findings highlight that viral lysis currently redirects about half (55\%) of seasonal phytoplankton carbon production towards the microbial loop, indicating that carbon sequestration by these Antarctic ecosystems is less effective than previously believed. This necessitates a reconsideration of the efficiency of the biological pump in Antarctic waters.

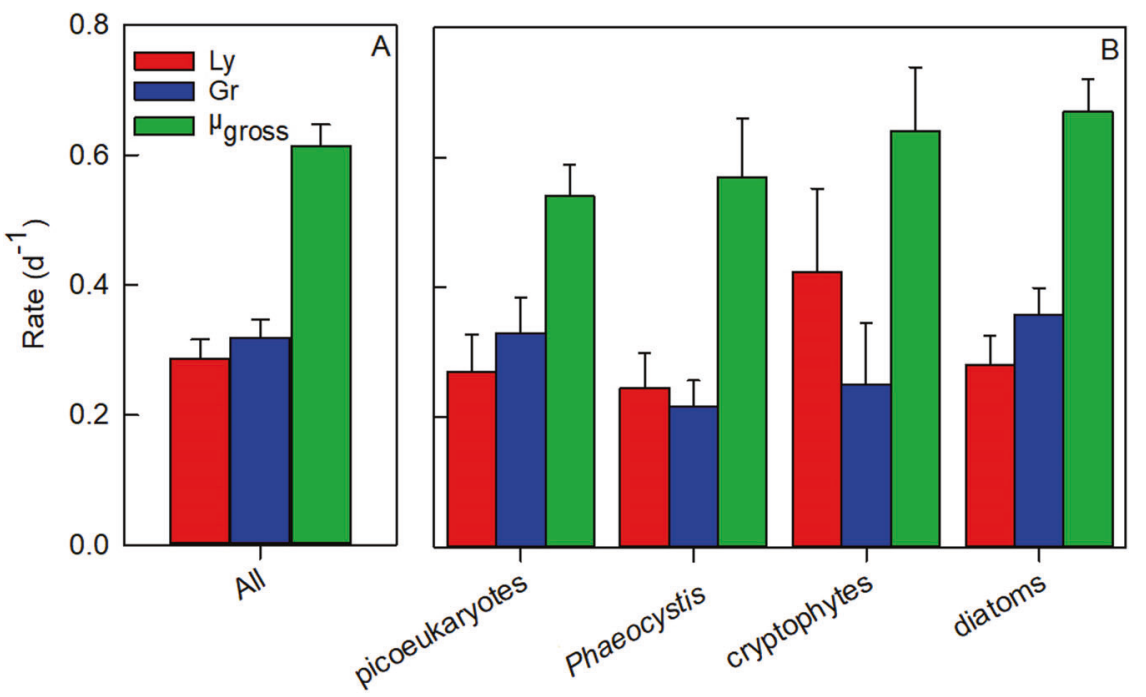

Fig. 4 Seasonal mean specific rates $\left(\mathbf{d}^{-1}\right)$ of viral lysis $(\mathrm{Ly})$, grazing $(\mathrm{Gr})$ and gross growth ( $\left.\boldsymbol{\mu}_{\text {gross }}\right)$. (A) All phytoplankton (All), and (B) per phytoplankton group: picoeukaryotes (Phyto I and II), Phaeocystis (Phyto III), cryptophytes (Phyto IV) and diatoms (Phyto V, VI, VIII and IX). Error bars represent \pm 1 standard error.
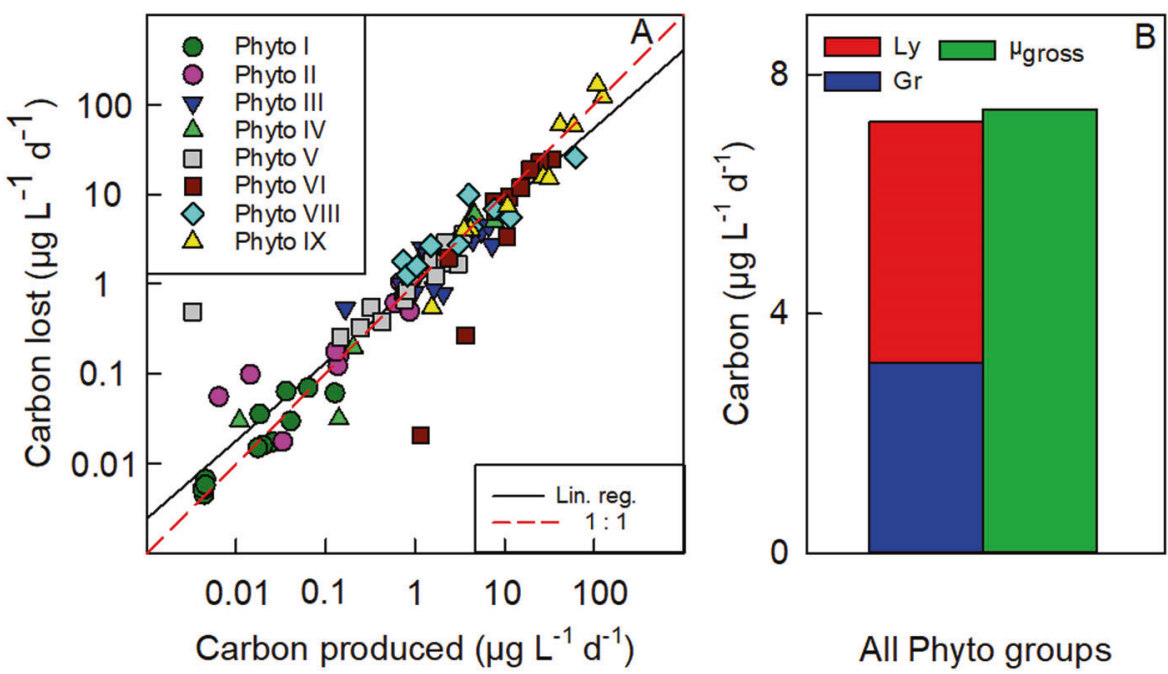

Fig. 5 Seasonal phytoplankton carbon production and losses. A Daily phytoplankton carbon lost by viral lysis and grazing plotted against daily carbon produced by gross growth of the phytoplankton populations. Different data points are from rate measurements at different time points during the season. B Seasonal mean of total phytoplankton carbon lost by viral lysis (Ly) and grazing (Gr) and total carbon produced by gross growth, overall phytoplankton groups. The regression line (solid black line) in (A) has a slope of $0.87\left(R^{2}=0.87 ; p<0.0001, n=95\right)$. Note: zeros $(n=1)$ and negative $(n=2)$ values were excluded from log transformed carbon data in (A). 


\section{DATA AVAILABILITY}

All data used in this publication, including the script used to test for significant differences between dilution series regressions; and a subset of representative flow cytometry files (consisting of four complete experiments from various time points throughout the season), are publicly available at https://dataverse.nioz.nl/dataset. xhtml?persistentld=doi:10.25850/nioz/7b.b.hc.

\section{REFERENCES}

1. Behrenfeld MJ, Boss ES. Student's tutorial on bloom hypotheses in the context of phytoplankton annual cycles. Glob Chang Biol. 2018;24:55-77.

2. Suttle CA. Marine viruses-major players in the global ecosystem. Nat Rev Microbiol. 2007;5:801-12.

3. Calbet A, Landry MR. Phytoplankton growth, microzooplankton grazing, and carbon cycling in marine systems. Limnol Oceanogr. 2004;49:51-7.

4. Baudoux A-C, Noordeloos AAM, Veldhuis MJW, Brussaard CPD. Virally induced mortality of Phaeocystis globosa during two spring blooms in temperate coastal waters. Aquat Micro Ecol. 2006;44:207-17.

5. Vardi A, Haramaty L, Van Mooy BAS, Fredricks HF, Kimmance SA, Larsen A, et al. Host-virus dynamics and subcellular controls of cell fate in a natural coccolithophore population. Proc Natl Acad Sci. 2012;109:19327-32.

6. Mojica KDA, Huisman J, Wilhelm SW, Brussaard CPD. Latitudinal variation in virusinduced mortality of phytoplankton across the North Atlantic Ocean. ISME J. 2016;10:500-13.

7. Safi KA, Brian Griffiths F, Hall JA. Microzooplankton composition, biomass and grazing rates along the WOCE SR3 line between Tasmania and Antarctica. Deep Sea Res Part I Oceanogr Res Pap. 2007:54:1025-41.

8. Brussaard CPD, Kuipers B, Veldhuis MJW. A mesocosm study of Phaeocystis globosa population dynamics I. Regulatory role of viruses in bloom control. Harmful Algae. 2005;4:859-74

9. Bratbak G, Egge JK, Heldal M. Viral mortality of the marine alga Emiliania huxleyi (Haptophyceae) and termination of algal blooms. Mar Ecol Prog Ser. 1993;93:39-48.

10. Brussaard CPD, Mari X, Van Bleijswijk JDL, Veldhuis MJW. A mesocosm study of Phaeocystis globosa (Prymnesiophyceae) population dynamics: II. Significance for the microbial community. Harmful Algae. 2005;4:875-93.

11. Wilhelm SW, Suttle CA. Viruses and nutrient cycles in the sea. Bioscience. 1999;49:781-8.

12. Brussaard CPD, Timmermans KR, Uitz J, Veldhuis MJW. Virioplankton dynamics and virally induced phytoplankton lysis versus microzooplankton grazing southeast of the Kerguelen (Southern Ocean). Deep Sea Res Part II Top Stud Oceanogr. 2008;55:752-65.

13. Weitz JS, Wilhelm SW. Ocean viruses and their effects on microbial communities and biogeochemical cycles. F1000 Biol Rep. 2012;4:2-9.

14. Brussaard CPD, Martínez J. Algal bloom viruses. Plant Viruses. 2008;2:1-13.

15. Nagasaki K. Dinoflagellates, diatoms, and their viruses. J Microbiol. 2008;46:235-43.

16. Coy SR, Gann ER, Pound HL, Short SM, Wilhelm SW. Viruses of eukaryotic algae: diversity, methods for detection, and future directions. Viruses. 2018;10:487.

17. Muhling M, Fuller NJ, Millard A, Somerfield PJ, Marie D, Wilson WH, et al. Genetic diversity of marine Synechococcus and co-occurring cyanophage communities: Evidence for viral control of phytoplankton. Environ Microbiol. 2005;7:499-508.

18. Haaber J, Middelboe M. Viral lysis of Phaeocystis pouchetii: Implications for algal population dynamics and heterotrophic C, N and P cycling. ISME J. 2009;3:430-41.

19. Brussaard CPD. Viral control of phytoplankton populations-a review. J Eukaryot Microbiol. 2004;51:125-38.

20. Evans C, Brussaard CPD. Viral lysis and microzooplankton grazing of phytoplankton throughout the Southern Ocean. Limnol Oceanogr. 2012;57:1826-37.

21. Brussaard CPD, Noordeloos AAM, Witte H, Collenteur MCJ, Schulz K, Ludwig A et al. Arctic microbial community dynamics influenced by elevated $\mathrm{CO}_{2}$ levels. Biogeosciences. 2013;10:719-31.

22. Khatiwala S, Tanhua T, Mikaloff Fletcher S, Gerber M, Doney SC, Graven HD, et al Global ocean storage of anthropogenic carbon. Biogeosciences. 2013;10:2169-91.

23. Frölicher TL, Sarmiento JL, Paynter DJ, Dunne JP, Krasting JP, Winton M. Dominance of the Southern Ocean in anthropogenic carbon and heat uptake in CMIP5 models. J Clim. 2015;28:862-86.

24. Bakker DCE, De Baar HJW, Bathmann UV. Changes of carbon dioxide in surface waters during spring in the Southern Ocean. Deep Sea Res Part II Top Stud Oceanogr. 1997;44:91-127.

25. Moreau S, Schloss IR, Mostajir B, Demers S, Almandoz GO, Ferrario ME, et al. Influence of microbial community composition and metabolism on air-sea $\Delta \mathrm{pCO}_{2}$ variation off the western Antarctic Peninsula. Mar Ecol Prog Ser. 2012;446:45-59.

26. Ducklow H, Clarke A, Dickhut R, Doney SC, Geisz H, Huang K, et al. The marine system of the Western Antarctic Peninsula. In: Rogers AD, Johnston NM, Murphy EJ, Clarke A, editors. Antarctic ecosystems: an extreme environment in a changing world. Blackwell Publishing Ltd.; 2012. pp. 121-59.
27. Shreeve RS, Ward P, Whitehouse MJ. Copepod growth and development around South Georgia: Relationships with temperature, food and krill. Mar Ecol Prog Ser. 2002;233:169-83.

28. Barrera-Oro E. The role of fish in the Antarctic marine food web: differences between inshore and offshore waters in the southern Scotia Arc and west Antarctic Peninsula. Antarct Sci. 2002;14:293-309.

29. Belton B, Thilsted SH. Fisheries in transition: Food and nutrition security implications for the global South. Glob Food Sec. 2014;3:59-66.

30. Turner JT. Zooplankton fecal pellets, marine snow, phytodetritus and the ocean's biological pump. Prog Oceanogr. 2015;130:205-48.

31. Gordon AL. Bottom water formation. In: Steele JH, Turekian KK, Thorpe SA, editors. Encyclopedia of ocean sciences, 1st ed. Elsevier; 2001. pp. 334-40.

32. Jacobs SS. Bottom water production and its links with the thermohaline circulation. Antarct Sci. 2004;16:427-37.

33. Petrou K, Baker KG, Nielsen DA, Hancock AM, Schulz KG, Davidson AT. Acidification diminishes diatom silica production in the Southern Ocean. Nat Clim Chang. 2019;9:781-6.

34. Sommer $U$, Lengfellner $K$. Climate change and the timing, magnitude, and composition of the phytoplankton spring bloom. Glob Chang Biol. 2008;14:1199-208.

35. Moline MA, Claustre H, Frazer TK, Schofield O, Vernet M. Alteration of the food web along the Antarctic Peninsula in response to a regional warming trend. Glob Chang Biol. 2004;10:1973-80.

36. Biggs TEG, Alvarez-Fernandez S, Evans C, Mojica KDA, Rozema PD, Venables HJ, et al. Antarctic phytoplankton community composition and size structure: importance of ice type and temperature as regulatory factors. Polar Biol. 2019;42:1997-2015

37. Clarke A, Meredith MP, Wallace MI, Brandon MA, Thomas DN. Seasonal and interannual variability in temperature, chlorophyll and macronutrients in northern Marguerite Bay, Antarctica. Deep Res Part II Top Stud Oceanogr. 2008;55:1988-2006.

38. Marie D, Partensky F, Vaulot D, Brussaard CPD. Enumeration of phytoplankton, bacteria, and viruses in marine samples. Curr Protoc Cytom. 1999;10:11.11.1-5.

39. Li WKW, Dickie PM. Monitoring phytoplankton, bacterioplankton, and virioplankton in a coastal inlet (Bedford Basin) by flow cytometry. Cytometry. 2001;44:236-46.

40. Vaulot D. CYTOPC: processing software for flow cytometric data. Signal Noise. 1989;2:8.

41. Biggs TEG, Brussaard CPD, Evans C, Venables HJ, Pond DW. Plasticity in dormancy behaviour of Calanoides acutus in Antarctic coastal waters. ICES J Mar Sci. 2020;77:1738-51.

42. Marie D, Brussaard CPD, Thyrhaug R, Bratbak G, Vaulot D. Enumeration of marine viruses in culture and natural samples by flow cytometry. Appl Environ Microbiol. 1999;65:45-52.

43. Mojica KDA, Evans C, Brussaard CPD. Flow cytometric enumeration of marine viral populations at low abundances. Aquat Microb Ecol. 2014;71:203-9.

44. Brussaard CPD, Payet JP, Winter C, Weinbauer MG. Quantification of aquatic viruses by flow cytometry. Man Aquat viral Ecol. 2010;11:102-9.

45. Lawrence JE, Brussaard CPD, Suttle CA. Virus-specific responses of Heterosigma akashiwo to infection. Appl Environ Microbiol. 2006;72:7829-34.

46. Tomaru Y, Nagasaki K. Flow cytometric detection and enumeration of DNA and RNA viruses infecting marine eukaryotic microalgae. J Oceanogr. 2007;63:215-21.

47. Jacquet $S$, Heldal M, Iglesias-Rodriguez D, Larsen A, Wilson W, Bratbak G. Flow cytometric analysis of an Emiliana huxleyi bloom terminated by viral infection. Aquat Micro Ecol. 2002;27:111-24.

48. Brussaard CPD. Optimization of procedures for counting viruses by flow cytometry. Appl Environ Microbiol. 2004;70:1506-13.

49. Brussaard CPD, Thyrhaug R, Marie D, Bratbak G. Flow cytometric analyses of viral infection in two marine phytoplankton species, Micromonas pusilla (Prasinophyceae) and Phaeocystis pouchetii (Prymnesiophyceae). J Phycol. 1999;35:941-8.

50. Kimmance SA, Wilson WH, Archer SD. Modified dilution technique to estimate viral versus grazing mortality of phytoplankton: Limitations associated with method sensitivity in natural waters. Aquat Microb Ecol. 2007;49:207-22.

51. Garrison DL, Gowing MM, Hughes MP, Campbell L, Caron DA, Dennett MR, et al Microbial food web structure in the Arabian Sea: A US JGOFS study. Deep Sea Res Part II Top Stud Oceanogr. 2000;47:1387-422.

52. Worden AZ, Nolan JK, Palenik B. Assessing the dynamics and ecology of marine picophytoplankton: the importance of the eukaryotic component. Limnol Oceanogr. 2004;49:168-79.

53. van Leeuwe MA, Webb AL, Venables HJ, Visser RJW, Meredith MP, Elzenga JTM, et al. Annual patterns in phytoplankton phenology in Antarctic coastal waters explained by environmental drivers. Limnol Oceanogr. 2020;65:1651-68.

54. Baudoux A-C, Veldhuis MJW, Witte HJ, Brussaard CPD. Viruses as mortality agents of picophytoplankton in the deep chlorophyll maximum layer during IRONAGES III. Limnol Oceanogr. 2007;52:2519-29. 
55. Baudoux A-C, Veldhuis MJW, Noordeloos AAM, van Noort G, Brussaard CPD. Estimates of virus- vs. grazing induced mortality of picophytoplankton in the North Sea during summer. Aquat Micro Ecol. 2008;52:69-82.

56. Kranzler CF, Krause JW, Brzezinski MA, Edwards BR, Biggs WP, Maniscalco M, et al. Silicon limitation facilitates virus infection and mortality of marine diatoms. Nat Microbiol. 2019;4:1790-7.

57. Tomaru Y, Takao Y, Suzuki H, Nagumo T, Nagasaki K. Isolation and characterization of a single-stranded RNA virus infecting the bloom-forming diatom Chaetoceros socialis. Appl Environ Microbiol. 2009;75:2375-81.

58. Kattner G, Hagen W. Lipids in marine copepods: Latitudinal characteristics and perspective to global warming. In: Kainz $M$, Brett $M$, Arts $M$, editors. Lipids in aquatic ecosystems. Springer New York; 2009. pp. 257-80.

59. Ploug $\mathrm{H}$, Iversen $\mathrm{MH}$, Fischer $\mathrm{G}$. Ballast, sinking velocity, and apparent diffusivity within marine snow and zooplankton fecal pellets: Implications for substrate turnover by attached bacteria. Limnol Oceanogr. 2008;53:1878-86.

60. Voss M. Content of copepod faecal pellets in relation to food supply in Kiel Bight and its effect on sedimentation rate. Mar Ecol Prog Ser. 1991;75:217-25.

61. Lønborg C, Middelboe M, Brussaard CPD. Viral lysis of Micromonas pusilla: Impacts on dissolved organic matter production and composition. Biogeochemistry. 2013;116:231-40.

62. Yamada $Y$, Tomaru $Y$, Fukuda $H$, Nagata T. Aggregate formation during the viral lysis of a marine diatom. Front Mar Sci. 2018;5:167.

63. Maat DS, Crawfurd KJ, Timmermans KR, Brussaard CPD. Elevated $\mathrm{CO}_{2}$ and phosphate limitation favor Micromonas pusilla through stimulated growth and reduced viral impact. Appl Environ Microbiol. 2014;80:3119-27.

64. Maat DS, Brussaard CPD. Both phosphorus- and nitrogen limitation constrain viral proliferation in marine phytoplankton. Aquat Micro Ecol. 2016;77:87-97.

65. Maat DS, de Blok R, Brussaard CPD. Combined phosphorus limitation and light stress prevent viral proliferation in the phytoplankton species Phaeocystis globosa, but Not in Micromonas pusilla. Front Mar Sci. 2016;3:160.

66. Maat DS, Biggs TEG, Evans C, van Bleijswijk JDL, van Der Wel NN, Dutilh BE, et al. Characterization and temperature dependence of arctic Micromonas polaris viruses. Viruses. 2017;9:6-9.

67. Piedade GJ, Wesdorp EM, Montenegro-Borbolla E, Maat DS, Brussaard CPD. Influence of irradiance and temperature on the virus MpoV-45T infecting the Arctic picophytoplankter Micromonas polaris. Viruses. 2018;10:676.

68. Gann ER, Gainer PJ, Reynolds TB, Wilhelm SW. Influence of light on the infection of Aureococcus anophagefferens CCMP 1984 by a "giant virus". PLoS ONE. 2020;15: e0226758.

69. Evans C, Wilson WH. Preferential grazing of Oxyrrhis marina on virus infected Emiliania huxleyi. Limnol Oceanogr. 2008;53:2035-40.

70. Vermont Al, Martínez Martínez J, Waller JD, Gilg IC, Leavitt AH, Floge SA, et al. Virus infection of Emiliania huxleyi deters grazing by the copepod Acartia tonsa. J Plankton Res. 2016;38:1194-205.

71. González JM, Suttle CA. Grazing by marine nanoflagellates on viruses and virussized particles: ingestion and digestion. Mar Ecol Prog Ser. 1993;94:1-10.

72. Rose JM, Caron DA. Does low temperature constrain the growth rates of heterotrophic protists? Evidence and implications for algal blooms in cold waters. Limnol Oceanogr. 2007;52:886-95.

73. Helenius LK, Saiz E. Feeding behaviour of the nauplii of the marine calanoid copepod Paracartia grani Sars: Functional response, prey size spectrum, and effects of the presence of alternative prey. PLoS ONE. 2017;12:e0172902.

74. Djeghri N, Atkinson A, Fileman ES, Harmer RA, Widdicombe CE, McEvoy AJ, et al. High prey-predator size ratios and unselective feeding in copepods: a seasonal comparison of five species with contrasting feeding modes. Prog Oceanogr. 2018;165:63-74.

75. Gonçalves RJ, Gréve H, van S, Couespel D, Kiørboe T. Mechanisms of prey size selection in a suspension-feeding copepod, Temora longicornis. Mar Ecol Prog Ser. 2014;517:61-74.

76. Zhao Z, Gonsior M, Schmitt-Kopplin P, Zhan Y, Zhang R, Jiao N, et al. Microbial transformation of virus-induced dissolved organic matter from picocyanobacteria: coupling of bacterial diversity and DOM chemodiversity. ISME J. 2019;13:2551-65.

77. Collins $M$, Knutti R, Arblaster J, Dufresne J-L, Fichefet $T$, Friedlingstein $P$, et al. Long-term climate change: Projections, commitments, and irreversibility. Climate change 2013: the physical science basis. Contribution of Working Group I to the Fifth Assessment Report of the Intergovernmental Panel on Climate Change. United Kingdom and NY, USA: Cambridge University Press; 2013.

78. Montes-Hugo M, Doney SC, Ducklow HW, Fraser W, Martinson D, Stammerjohn SE, et al. Recent changes in phytoplankton communities associated with rapid regional climate change along the western Antarctic Peninsula. Science. 2009;323:1470-3.

79. Arrigo KR, van Dijken GL. Continued increases in Arctic Ocean primary production. Prog Oceanogr. 2015;136:60-70.

80. Vernet M, Martinson D, lannuzzi R, Stammerjohn S, Kozlowski W, Sines K, et al. Primary production within the sea-ice zone west of the Antarctic Peninsula: I-
Sea ice, summer mixed layer, and irradiance. Deep Sea Res Part II Top Stud Oceanogr. 2008;55:2068-85.

81. Deppeler SL, Davidson AT. Southern Ocean phytoplankton in a changing climate. Front Mar Sci. 2017;4:40.

82. Van de Poll WH, Kulk G, Rozema PD, Brussaard CPD, Visser RJW, Buma AGJ. Contrasting glacial meltwater effects on post-bloom phytoplankton on temporal and spatial scales in Kongsfjorden. Spitsbergen Elem Sci Anth. 2018;6:50.

83. Ardyna M, Babin M, Gosselin M, Devred E, Rainville L, Tremblay J-É. Recent Arctic Ocean sea ice loss triggers novel fall phytoplankton blooms. Geophys Res Lett. 2014;41:6207-12.

84. Venables HJ, Clarke A, Meredith MP. Wintertime controls on summer stratification and productivity at the western Antarctic Peninsula. Limnol Oceanogr. 2013;58:1035-47.

85. Mendes CRB, Tavano VM, Dotto TS, Kerr R, de Souza MS, Garcia CAE, et al. New insights on the dominance of cryptophytes in Antarctic coastal waters: a case study in Gerlache Strait. Deep Sea Res Part II Top Stud Oceanogr. 2017;149:161-70.

86. Rozema PD, Venables HJ, van de Poll WH, Clarke A, Meredith MP, Buma AGJ. Interannual variability in phytoplankton biomass and species composition in northern Marguerite Bay (West Antarctic Peninsula) is governed by both winter sea ice cover and summer stratification. Limnol Oceanogr. 2017;62:235-52.

\section{ACKNOWLEDGEMENTS}

We thank the British Antarctic Survey for their logistical support and cooperation during the field campaign as well as Zoi Farenzena for field assistance. We thank the anonymous reviewers for their constructive comments on the paper. This work was part of the ANTPHIRCO project (grant 866.10.102 awarded to CPDB) which was supported by the Netherlands Polar Programme and with financial aid from the Dutch Research Council (NWO).

\section{AUTHOR CONTRIBUTIONS}

CPDB has initiated the research and had the project oversight; TEGB and CPDB were responsible for research design and data analysis; TEGB performed the research; $\mathrm{JH}$ contributed to statistical analysis. All authors contributed to results interpretation and the writing of the paper.

\section{COMPETING INTERESTS}

The authors declare no competing interests.

\section{ADDITIONAL INFORMATION}

Supplementary information The online version contains supplementary material available at https://doi.org/10.1038/s41396-021-01033-6.

Correspondence and requests for materials should be addressed to T.E.G.B.or C.P.D.B.

Reprints and permission information is available at http://www.nature.com/ reprints

Publisher's note Springer Nature remains neutral with regard to jurisdictional claims in published maps and institutional affiliations.

Open Access This article is licensed under a Creative Commons Attribution 4.0 International License, which permits use, sharing, adaptation, distribution and reproduction in any medium or format, as long as you give appropriate credit to the original author(s) and the source, provide a link to the Creative Commons license, and indicate if changes were made. The images or other third party material in this article are included in the article's Creative Commons license, unless indicated otherwise in a credit line to the material. If material is not included in the article's Creative Commons license and your intended use is not permitted by statutory regulation or exceeds the permitted use, you will need to obtain permission directly from the copyright holder. To view a copy of this license, visit http://creativecommons. org/licenses/by/4.0/.

(c) The Author(s) 2021 